\title{
Patricia A. McCormack, Fort Chipewyan and the Shaping of Canadian History, 1788-1920s "We like to free in this country" (Vancouver: UBC Press, 2010).
}

Even today, when the ice highway melts in March, Fort Chipewyan cannot be reached by road. Yet it still occupies an importance in modern Alberta and Canada that far exceeds its size due to its relative proximity downstream on the Athabasca River from the Fort McMurray oilsands, often described as the engine of Canada's economy. If the reader suspects this is exaggeration, consider this: how many elementary schools in small town Canada can attract a corporate sponsorship?

In its early history after its establishment in 1788 on the shores of Lake Athabasca, Fort Chipewyan's importance was much greater. For a time it dominated the fur trade, then the backbone of the economy in the Northwest. Patricia A. McCormack's book describes how the fur trade brought together Chipewyan, Cree, Metis, French, and English/Scottish people to form what she insists was always a modern community. She reveals how the political and economic changes in the Northwest, and later Canada, played a role in shaping the town's culture. Far from the centre of white settlement and unaffected by the destruction of the plains Indian economy based on the buffalo, the residents of Fort Chipewyan enjoyed an independence in livelihood and action denied aboriginal people further south. Euro-Canadians, politics, and development have continually altered Fort Chipewyan, often not to the advantage of the residents, however McCormack argues in Chapter 9 that nevertheless, the local people cannot be portrayed as subalterns or subordinate people. Several times in the book she returns to the quotation from Alexandre Laviolette, a Chipewyan chief, also used as the subtitle of the book: "We like to be free in this country."

McCormack's approach is to avoid the distractions of the colourful, often violent, activities of white traders in the days of competition in the fur trade in order to concentrate on the development of Fort Chipewyan society through to the 1920s. The book reads as not just a history of Fort Chipewyan, but also as a commentary on her earlier writing about this community. Chapter 3, for example, is called "The Fur Trade Mode of Production," a similar title to an essay she first wrote in 1984. By comparing Fort Chipewyan society to classical capitalist models, the chapter analyses the division of labour of the Europeans, Metis, and Indians in the fur trade. The model also provides a method to think about gender roles. In the end, McCormack concluded that the classical model does not work well in Fort Chipewyan. There was not a clear division of labour. All the races hunted together. Europeans often adopted 
aboriginal technology and they intermarried. Traders did not change the fundamental society.

In later chapters McCormack uses an analytical approach popularized in the 1990s by historians such as Jean and John Comaroff who concluded that colonialism transforms the consciousness of its subjects in ways they may not be fully aware of. Influences such as education, religion, and the imposition of law may not directly aim at conquest, but help to accomplish it. Although sympathetic to this argument as it applies to aboriginal people in Canada and conscious of the expectation of Canadian bureaucracy that aboriginal people would be assimilated, McCormack also identifies instances of resistance, if not at Fort Chipewyan, then in neighbouring Treaty 8 regions.

When faced with the decision of accepting Treaty 8 or "Metis" scrip in 1899, aboriginal people in Fort Chipewyan were at a relative disadvantage, but they were not naive. They knew the history of Treaty 6 and had spoken to Metis from the South. They did not want to be restricted to living on reserves. They negotiated future hunting, fishing, and trapping rights and in the case of Alexandre Laviolette, access to Roman Catholic Schools. He also wanted a railroad, a convenience not promised and yet to be realized. The problem was not negotiating, but having the negotiated rights honoured.

In her epilogue McCormack argued that Fort Chipewayn people have always successfully adjusted to economic and cultural change. For the most part, Fort Chipewyan people have assimilated outsiders rather than assimilating to outside society. She concludes the community had more difficulty adjusting in post-treaty Canada with the imposition of Euro-Canadian managers. Yet, she states they never lost sight of their wish to be free, and with the help of court rulings since the 1970s they are acquiring the tools that they need to do so.

Daniel Johns

Alberta Ombudsman

\section{Terry Sullivan, The Cburch of the Empire Versus the Christian Cburch of North Africa: 312-430 AD (Denver: Radical Christian Press, 2012).}

During a recent presentation at U.C. Berkeley, Princeton professor of African American Studies Cornell West commented, "Most of Christianity is Constantinian Christianity." What did he mean? In his new book, The Church of the Empire, the church historian and former New York Catholic Worker associate, Terry Sullivan, endeavors to give us an answer to this in his account of the 